\title{
Bacterial Blight of Leek: A New Disease in California Caused by Pseudomonas syringae
}

\author{
Steven T. Koike, University of California Cooperative Extension, Salinas 93901; Jeri D. Barak, Department of \\ Plant Pathology, University of California, Davis 95616; Diana M. Henderson, University of California Coopera-
} tive Extension, Salinas; and Robert L. Gilbertson, Department of Plant Pathology, University of California, Davis

\begin{abstract}
Koike, S. T., Barak, J. D., Henderson, D. M., and Gilbertson, R. L. 1999. Bacterial blight of leek: A new disease in California caused by Pseudomonas syringae. Plant Dis. 83:165-170.

During 1996 and 1997, a new and damaging disease of leek (Allium porrum) was observed on greenhouse-produced transplants and field-grown plants in California. Symptoms were watersoaked lesions at leaf tips, which eventually expanded down the length of the leaf and resulted in brown, elongated, stripe-like lesions with yellow margins. Diseased leaves eventually wilted. A blue fluorescent pseudomonad was consistently recovered from lesions, and biochemical and physiological tests indicated that it was Pseudomonas syringae. Pathogenicity tests established that representative strains of this $P$. syringae induced disease symptoms in leek that were similar to those observed on leek plants in the greenhouse and field, and that this bacterium caused similar symptoms in onion, chives, and garlic plants. Representative strains were further characterized by fatty acid analysis, repetitive bacterial sequence-polymerase chain reaction (repPCR), and rDNA sequencing. Fatty acid analysis confirmed that these isolates were P. syringae, but did not provide a clear pathovar designation. Rep-PCR analysis revealed that all the California leek $P$. syringae strains had identical DNA fingerprints and that these strains were indistinguishable from those of known strains of $P$. syringae pv. porri. In addition, the rDNA sequence of the spacer region between $16 \mathrm{~S}$ and 23S rDNA genes was identical among the California leek $P$. syringae strains and $P$. syringae pv. porri. Together, these results established that the new leek disease in California is caused by $P$. syringae pv. porri. P. syringae pv. porri was recovered from a commercial leek seed lot imported into California, which suggests that the pathogen was introduced in association with seed. Commercial leek production in California is favorable for development of this disease because transplants are produced in greenhouses with high plant densities, overhead irrigation, and mowing of plants.
\end{abstract}

Leek (Allium porrum) is one of the many important minor crops grown in California. Planted acreage of this crop has been increasing in recent years and, in 1997, over 360 acres were grown with a value of almost $\$ 3$ million (1). In California, the leek crop is usually grown from seed imported from Europe. Seeds are planted in plug trays, grown for 80 to 100 days in greenhouses, and then usually mowed twice to promote uniformity and root development and to increase thickness of the plants. Mowing involves passing leek plug trays underneath modified lawnmowers so that remaining foliage and stems are approximately 6 to $10 \mathrm{~cm}$ high. After re-growth, these greenhouse-grown transplants are then planted in the field and are generally sprinkler-irrigated.

Corresponding author: S. T. Koike

E-mail: stkoike@ucdavis.edu

First and second authors should be considered joint first authors.

Accepted for publication 13 October 1998.

Publication no. D-1998-1214-07R

(C) 1999 The American Phytopathological Society
In 1996, a previously unreported foliar disease of leek in California was observed in commercial transplant greenhouses as well as in fields in several coastal counties (Monterey, Santa Cruz, and Ventura). Initial symptoms were water-soaked, longitudinal lesions starting at leaf tips and extending down into the leaf. As these lesions expanded and elongated, chlorotic borders developed, and eventually leaves wilted and died. Symptoms were most prevalent on seedlings that had been mowed. In field-grown plants, lesions extended into the plant sheath, which caused the leaves to curl, split, and eventually desiccate. Severely affected plants were stunted, misshapen, and unharvestable. When examined with a microscope, cut edges of symptomatic leaves consistently exhibited bacterial streaming. The purpose of this study was to determine the causal agent and the etiology of this disease. A preliminary report has been published (9).

\section{MATERIALS AND METHODS}

Bacterial strains. All strains were stored at $-80^{\circ} \mathrm{C}$ in a yeast tryptone $80 \%$ glycerol solution (18; Table 1). From our collection of bacterial strains isolated from leek in California, 20 representative strains were chosen for biochemical and genetic characterization. Additional Pseudomonas syringae strains from California, Canada, and France (Table 1) were used for identification and characterization. These strains were checked for pathogenicity on their respective hosts.

Isolation of the causal agent. Sections of leek leaves with symptoms were surface disinfested $(0.525 \%$ sodium hypochlorite; $1 \mathrm{~min}$ ) and small pieces of tissue were removed from the margins of lesions and either macerated in a drop of sterile distilled water and streaked onto sucrose peptone agar, or placed intact onto acidified potato-dextrose agar $(2 \mathrm{ml}$ lactic acid/liter). Plates were incubated at $24^{\circ} \mathrm{C}$ and examined after 2 to 5 days for bacterial or fungal growth, respectively.

Pathogenicity and host range. To establish pathogenicity of the bacterial strains recovered from diseased leek leaves or from seed, nutrient broth shake cultures were grown for $48 \mathrm{~h}$. Sterile Tween $20(60$ $\mu \mathrm{l} / 100 \mathrm{ml})$ was added to these cultures $(1 \times$ $10^{7} \mathrm{CFU} / \mathrm{ml}$ as determined by dilution plating) prior to inoculation. Leek plants (3 months old) of four cultivars (Table 2) were spray-inoculated until runoff with a hand-held mister. Plants then were incubated for $48 \mathrm{~h}$ in a humidity chamber. Negative control plants were inoculated with sterile nutrient broth and incubated in the same way. All plants then were maintained in a greenhouse $\left(23\right.$ to $\left.27^{\circ} \mathrm{C}\right)$ and examined for disease symptoms after 5 to 9 days. Inoculations were conducted twice with strains recovered from California leek plants and once with known $P$. syringae strains that had been isolated from leek in Canada and France (Table 1).

To test pathogenicity of the bacterial strains on hosts other than leek, representative strains were inoculated onto plants as described above. A total of 10 strains were inoculated onto the following Allium spp.: onion (A. серa cvs. Early Red Burger and Stockton Early Yellow), chives ( $A$. schoenoprasum), and garlic (A. sativum). Four strains were inoculated onto the following non-Allium spp. in the Liliaceae family: Lily-of-the-Nile (Agapanthus africanus cv. Peter Pan) and daylily (Hemerocallis hybrid Stella D'Oro). In addition, the following non-Liliaceae plants also were inoculated: bean (Phaseolus vulgaris cv. Blue Lake), cauliflower (Brassica oleracea var. botrytis cv. White Rock), celery (Apium graveolens cv. 52-70R), pea (Pisum 
sativum cv. Sugar Snap), tomato (Lycopersicon esculentum cv. Early Girl), and marigold (Tagetes erecta cv. Aurora Red).

In addition to the spray inoculations, rub inoculations were performed on the two Liliaceae hosts and the six non-Liliaceae hosts by adding Carborundum to nutrient broth shake cultures and gently rubbing the inoculum onto leaf surfaces using cotton swabs. For all spray and rub inoculations of non-leek plants, leek plants (cv. Gavilan) were included as positive controls and negative controls of all plant species were inoculated with sterile nutrient broth. All inoculations were conducted twice.

Biochemical characterization of the pathogen. All strains isolated from symptomatic plants and seed washings were checked for fluorescence. Strains were grown on King's medium $\mathrm{B}(\mathrm{KB} ; 7)$ and fluorescence was evaluated visually using a hand-held UV lamp (long wave UV; 280 $\mathrm{nm})$. Fluorescent pseudomonads were evaluated for LOPAT (11) characteristics, which include production of arginine dihydrolase, levan, and oxidase, ability to rot potato, and induction of the hypersensitive reaction in tobacco (Nicotiana tabacum $\mathrm{cv}$. Havana 425) leaves.

Fatty acid analysis. Strains were initially recovered from storage by streaking onto 523 medium (6; Table 1). Bacterial strains were grown on trypticase soy broth agar for $24 \mathrm{~h}$ and fatty acids were prepared according to manufacturer's instructions (16). Whole cell fatty acid analysis was carried out by high performance liquid chromatography (HPLC). Fatty acid profiles were determined for each strain using the gram negative database in the Microbial Identification System (MIS) software package (MIS version no. 3.8, September 1994 update; MIDI, Inc., Newark, DE). The profiles for each strain were compared with available reference strains in the MIS library.

DNA extraction for repetitive bacterial sequence-polymerase chain reaction and rDNA sequencing. The strains used in sequencing analyses are listed in Table 1. A single colony from a $24-\mathrm{h}$-old bacterial culture grown on 523 medium was used to inoculate $2 \mathrm{ml}$ of yeast tryptone solution in a 3-ml polypropylene tube (Fisher Scientific Co., Pittsburgh). Tubes

Table 1. Pseudomonas syringae strains used for fatty acid analysis, rDNA sequencing, and repetitive bacterial sequence-polymerase chain reaction (rep-PCR)

\begin{tabular}{|c|c|c|c|c|c|}
\hline$P$ syringae strain & Host source & Location & $\begin{array}{l}\text { Fatty } \\
\text { acid }\end{array}$ & $\begin{array}{c}\text { Spacer } \\
\text { sequence }\end{array}$ & $\begin{array}{l}\text { rep- } \\
\text { PCR }\end{array}$ \\
\hline $1-2$ & Allium porrum, seed & California & + & + & + \\
\hline $2-7$ & Allium porrum, seed & California & + & $\ldots$ & + \\
\hline $2-11$ & Allium porrum, seed & California & + & $\ldots$ & + \\
\hline 372 & Allium porrum & California & + & $\ldots$ & + \\
\hline $96-83 a$ & Allium porrum & California & + & $\ldots$ & + \\
\hline $96-83 c$ & Allium porrum & California & + & $\ldots$ & + \\
\hline $96-39$ & Allium porrum & California & + & $\ldots$ & + \\
\hline $96-47$ & Allium porrum & California & + & $\ldots$ & + \\
\hline $96-50$ & Allium porrum & California & + & $\ldots$ & + \\
\hline $96-53$ & Allium porrum & California & + & $\ldots$ & + \\
\hline $96-03$ & Allium porrum & California & + & $\ldots$ & + \\
\hline $96-08$ & Allium porrum & California & + & $\ldots$ & + \\
\hline $96-87$ & Allium porrum & California & + & $\ldots$ & + \\
\hline $96-89$ & Allium porrum & California & + & + & + \\
\hline $96-75$ & Allium porrum & California & + & + & + \\
\hline $96-78$ & Allium porrum & California & + & $\ldots$ & + \\
\hline $96-14$ & Allium porrum & California & + & $\ldots$ & + \\
\hline $96-19$ & Allium porrum & California & + & $\ldots$ & + \\
\hline $96-28$ & Allium porrum & California & + & $\ldots$ & + \\
\hline $96-30$ & Allium porrum & California & + & $\ldots$ & + \\
\hline pv. porri 15 & Allium porrum & France & $\ldots$ & $\ldots$ & + \\
\hline pv. porri 22 & Allium porrum & Canada & $\ldots$ & $\ldots$ & + \\
\hline pv. porri 56 & Allium porrum & France & + & + & + \\
\hline pv. porri 59 & Allium porrum & France & + & $\ldots$ & + \\
\hline pv. porri 60 & Allium porrum & France & + & + & + \\
\hline pv. maculicola 328 & Brassica oleracea & California & $\ldots$ & + & $\ldots$ \\
\hline pv. maculicola 308 & Brassica oleracea & California & $\ldots$ & + & + \\
\hline pv. maculicola 395 & Brassica oleracea & California & $\ldots$ & $\ldots$ & + \\
\hline pv. phaseolicola 216 & Phaseolus vulgaris & California & $\ldots$ & + & + \\
\hline pv. pisi 539 & Pisum sativum & California & $\ldots$ & + & + \\
\hline pv. papulans A & Malus domestica & New York & $\ldots$ & + & + \\
\hline pv. papulans B & Malus domestica & New York & $\ldots$ & + & + \\
\hline pv. apii 152 & Apium graveolens & California & $\ldots$ & $\ldots$ & + \\
\hline pv. apii 153 & Apium graveolens & California & $\ldots$ & $\ldots$ & + \\
\hline pv. apii 212 & Apium graveolens & California & $\ldots$ & + & + \\
\hline pv. apii 285 & Apium graveolens & California & $\ldots$ & + & + \\
\hline pv. tomato 357 & Lycopersicon esculentum & California & $\ldots$ & + & + \\
\hline pv. tomato 359 & Lycopersicon esculentum & California & $\ldots$ & + & + \\
\hline pv. tomato 455 & Lycopersicon esculentum & California & $\ldots$ & $\ldots$ & + \\
\hline pv. tomato 456 & Lycopersicon esculentum & California & $\ldots$ & $\ldots$ & + \\
\hline
\end{tabular}

were placed on a shaker for $30 \mathrm{~h}$ at $28^{\circ} \mathrm{C}$. Bacterial cells were recovered by centrifugation and the pellet was resuspended in $800 \mu \mathrm{l}$ of cetyltrimethylammonium bromide (CTAB) buffer (22) that had been prewarmed to $60^{\circ} \mathrm{C}$. This cell suspension was incubated for $20 \mathrm{~min}$ at $60^{\circ} \mathrm{C}$. After incubation, $600 \mu \mathrm{l}$ of chloroform:octanol (24:1) was added and the suspension was vortexed for $2 \mathrm{~min}$. This suspension was centrifuged for $5 \mathrm{~min}(14,000 \times g)$ and the supernatant was collected and placed into a new 1.5-ml Eppendorf tube. Nucleic acids were precipitated by the addition of an equal volume of ice-cold isopropanol and then placed on ice for $10 \mathrm{~min}$. The tubes were then centrifuged for $8 \mathrm{~min}(14,000 \times$ $g$ ) and the nucleic acid pellet was washed with $500 \mu \mathrm{l}$ of $70 \%$ ethanol, dried, and resuspended in $100 \mu \mathrm{l}$ of water.

Repetitive bacterial sequence and rDNA polymerase chain reaction. To determine the relationship between the Pseudomonas syringae strains causing the leek disease in California and other $P$. syringae pathovars, polymerase chain reaction of repetitive bacterial sequences (repPCR) was used. PCR amplification of repetitive sequences was accomplished with the following primers: repetitive extragenic palindromic (REP)-PCR primers $1 \mathrm{R}$ (5'-III-ICG-ICG-ICA-TCI-GGC-3') and 2I (5'-ICG-ICT-TAT-CIG-GCC-TAC$\left.3^{\prime}\right)$; enterobacterial repetitive intergenic consensus (ERIC)-PCR primers $1 \mathrm{R}$ (5'ATG-TAA-GCT-CCT-GGG-GAT-TCA-C$\left.3^{\prime}\right)$ and $2 \mathrm{I}$ (5'-AAG-TAA-GTG-ACTGGG-GTG-AGC-G-3'); and BOX element 1A (BOX)-PCR primer 1R (5'-CTA-CGGCAA-GGC-GAC-GCT-GAC-G-3') (16). The PCR was carried out in a $25-\mu l$ reaction volume. Unless stated otherwise, all values for concentrations of chemicals correspond to final concentrations. The 23$\mu l$ PCR reaction included $5 \mu$ of buffer $\left(200 \mathrm{mM}\left[\mathrm{NH}_{4}\right]_{2} \mathrm{SO}_{4} ; 200 \mathrm{mM}\right.$ Tris- $\mathrm{HCl}$, $\mathrm{pH} 8.8 ; 200 \mathrm{mM} \mathrm{MgCl}_{2}$; and $100 \mathrm{mM}$ EDTA, pH 8.8), $0.2 \mu \mathrm{l}$ of dimethylsulfoxide, $1.25 \mu \mathrm{l}$ of deoxynucleoside triphosphate (dNTP) mixture (concentration of each dNTP, $5 \mathrm{mM}$ ), $1.25 \mu \mathrm{l}$ of each oli-

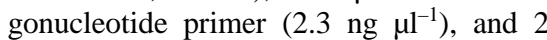
units of Taq polymerase (Perkin Elmer, Foster City, CA). To this PCR reaction mixture, $2 \mu$ of total genomic DNA (10 ng $\mu^{-1}$ ) was added. The PCR was carried out in a DNA Thermal Cycler 480 (PerkinElmer Cetus, Emeryville, CA). The amplification profile was an initial denaturation step of $95^{\circ} \mathrm{C}$ for $6 \mathrm{~min}$ followed by 35 cycles of $94^{\circ} \mathrm{C}$ for $1 \mathrm{~min}, 44^{\circ} \mathrm{C}$ for $1 \mathrm{~min}$, $65^{\circ} \mathrm{C}$ for $8 \mathrm{~min}$ for REP; $94^{\circ} \mathrm{C}$ for $1 \mathrm{~min}$, $52^{\circ} \mathrm{C}$ for $1 \mathrm{~min}, 65^{\circ} \mathrm{C}$ for $8 \mathrm{~min}$ for ERIC; $94^{\circ} \mathrm{C}$ for $1 \mathrm{~min}, 53^{\circ} \mathrm{C}$ for $1 \mathrm{~min}, 65^{\circ} \mathrm{C}$ for 8 min for BOX, and a final extension step of $65^{\circ} \mathrm{C}$ for $16 \mathrm{~min}$ (17). Amplified DNA fragments were examined by agarose gel electrophoresis in $1.5 \%$ agarose gels in $0.5 \times$ Tris-borate EDTA buffer. Gels were stained with ethidium bromide and DNA 
was visualized with a gel imaging system (Alpha Innotech Corporation, San Leandro, CA).

The $16 \mathrm{~S}-23 \mathrm{~S}$ rDNA spacer region of $P$. syringae pvs. porri, phaseolicola, pisi, papulans, apii, tomato, maculicola, and California leek strains (Table 1) was amplified with primers G1 (5'-GAA-GTC-GTAACA-AGG-3') and L1 (5'-CAA-GGCATC-CAC-CGT-3') (5). The PCR was carried out in a 50- $\mu$ l reaction volume. Unless stated otherwise, all values for concentrations of chemicals correspond to final concentrations. A 2- $\mu$ l aliquot of bac-

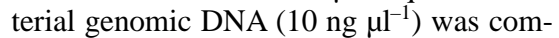
bined with $2.5 \mu$ l of reaction buffer $(25$ $\mathrm{mM} \mathrm{KCl} ; 5 \mathrm{mM}$ Tris- $\mathrm{HCl}, \mathrm{pH} 8.8$ at $25^{\circ} \mathrm{C}$; and $7.5 \mathrm{mM} \mathrm{MgCl}_{2}$ ), $1 \mu \mathrm{l}$ of dNTP mixture (concentration of each dNTP, $0.2 \mathrm{mM}$ ), $1.25 \mu \mathrm{l}$ of each oligonucleotide primers (primers G1 and L1; concentration, $1.25 \mathrm{ng}$ $\mu \mathrm{l}^{-1}$ ), and $40 \mu \mathrm{l}$ of deionized water. This solution was heated for $5 \mathrm{~min}$ at $94^{\circ} \mathrm{C}$, then 1.3 units of $T a q$ polymerase (Perkin Elmer) were added with $1.7 \mu \mathrm{l}$ of deionized water. The PCR was carried out in a Perkin Elmer GeneAmp 2400 with the following parameters: $1 \mathrm{~min}$ at $94^{\circ} \mathrm{C}, 7 \mathrm{~min}$ at $55^{\circ} \mathrm{C}$, and $2 \mathrm{~min}$ at $72^{\circ} \mathrm{C}(5)$. The final cycle was followed by an additional $7 \mathrm{~min}$ at $72^{\circ} \mathrm{C}$. Reactions $(7 \mu \mathrm{l})$ were examined by electrophoresis in $1 \%$ agarose gels in Trisacetate EDTA (TAE) buffer. Gels were stained with ethidium bromide and DNA was visualized as previously described. PCR-amplified DNA was recovered using silica matrix (Bio 101, Inc., Vista, CA) according to the manufacturer's suggestions. Sequences of PCR-amplified DNA fragments were determined with ABI PRISM Dye Terminator Cycle Sequencing with dRhodamine terminator chemistry and the reactions were run on an $\mathrm{ABI}$ PRISM 377 DNA Sequencer (Perkin Elmer) using a 5\% Long Ranger gel. The data were analyzed using ABI Prism Á Sequencing 2.1.1 software (Perkin Elmer). DNA sequence comparisons were done with the software of the Genetics Computer Group, University of WisconsinMadison (2).

Seed assay. A modified seed wash assay was conducted to investigate the possible association of the leek $P$. syringae with seed (13). A total of $20 \mathrm{~g}$ of seed (approximately 6,000 seeds) were placed into a $250-\mathrm{ml}$ flask containing $100 \mathrm{ml}$ of chilled $0.1 \mathrm{M}$ potassium phosphate buffer and $30 \mu \mathrm{l}$ of sterile Tween 20 . The flask was shaken at $200 \mathrm{rpm}$ for $4 \mathrm{~h}$ at $4^{\circ} \mathrm{C}$. The suspension was filtered through sterile cheesecloth and centrifuged for $10 \mathrm{~min}$ at $10,000 \times g$. The resulting pellet was resuspended in $2 \mathrm{ml}$ of potassium phosphate buffer, and serial dilutions $\left(10^{0}\right.$ to $\left.10^{-4}\right)$ were prepared with phosphate buffer. Aliquots $(100 \mu \mathrm{l})$ of each dilution were spread onto plates containing KBC medium (15). $\mathrm{KBC}$ plates were incubated for $24 \mathrm{~h}$ at $28^{\circ} \mathrm{C}$ and putative $P$. syringae colonies were identified by examining for fluorescence under UV light. These colonies were tested for pathogenicity on leek as previously described. Seed lots were assayed at least three times.

\section{RESULTS}

Association and isolation of a fluorescent pseudomonad from diseased leek leaves. A foliar fungal disease caused by Alternaria porri has recently damaged leek transplants and field crops in coastal California (8). However, neither A. porri nor any other fungal agent was isolated from leek leaves showing these necrotic longitudinal lesions. However, bacterial streaming was consistently observed from such lesions and fluorescent pseudomonads were consistently isolated from lesions on transplants and field-grown leeks. These results suggested a possible bacterial etiology for the disease. Representative strains of this fluorescent pseudomonad were streaked twice onto KB medium and then stored for additional study.

Pathogenicity and host range. A total of 33 fluorescent pseudomonad strains recovered from leek plants from various locations in California were inoculated onto plants of four leek cultivars; all of these strains induced water-soaked lesions at the tips of leaves that expanded into longitudinal necrotic lesions with chlorotic margins (Table 2). Onions, chives, and garlic also developed similar symptoms when inoculated with 10 representative strains. Fluorescent pseudomonads were reisolated from symptomatic leaves of all inoculated plants and were physiologically identical to the inoculated strains. Control plants inoculated with nutrient broth did not develop symptoms, nor were fluorescent pseudomonads isolated from leaves of these plants. Similar results were obtained in two independent inoculation experiments, and all tested strains gave similar results.

For both spray and rub inoculations, no symptoms developed on any of the nonAllium spp., Liliaceae family, or non-Liliaceae plants inoculated with the fluorescent pseudomonad from leek, nor were bacteria recovered from leaves of these plants (Table 2). Leek plants inoculated with the same strains used in these experiments developed typical symptoms and the pathogen was reisolated from leaf lesions.

Biochemical characterization of the pathogen. Fluorescent pseudomonad strains recovered from diseased leeks, including 18 of those used for pathogenicity tests and 2 recovered from seed, had similar colony morphologies; produced blue fluorescence on KB medium; were negative for cytochrome oxidase, arginine dihydrolase, and ability to rot potatoes; and were positive for production of levan from sucrose and induction of the hypersensitive reaction in tobacco leaves. These presumptive results indicate that the pathogen causing the leek disease in California is $P$. syringae.

Table 2. Pathogenicity of Pseudomonas syringae strains isolated from diseased leek plants in California on four leek cultivars, various Allium spp., non-Allium spp. Liliaceae plants, and nonLiliaceae plants

\begin{tabular}{|c|c|c|}
\hline \multirow[b]{2}{*}{ Inoculated plant } & \multicolumn{2}{|c|}{ Pathogenicity $^{\mathrm{a}}$} \\
\hline & Disease symptoms & Pathogen reisolated \\
\hline \multicolumn{3}{|l|}{ Leek cultivars $^{\mathrm{b}}$} \\
\hline Broad London & + & + \\
\hline Gavilan & + & + \\
\hline Otina & + & + \\
\hline Titan & + & + \\
\hline Leek negative controls & - & - \\
\hline \multicolumn{3}{|l|}{ Allium spp. } \\
\hline Onion cv. Early Red Burger & + & + \\
\hline Onion cv. Stockton Early Yellow & + & + \\
\hline Chives & + & + \\
\hline Garlic & + & + \\
\hline Leek positive controls & + & + \\
\hline All negative controls & - & - \\
\hline \multicolumn{3}{|l|}{ Liliaceae, non-Allium spp. ${ }^{c}$} \\
\hline Lily-of-the-Nile & - & - \\
\hline Daylily & - & - \\
\hline Leek positive control & + & + \\
\hline All negative controls & - & - \\
\hline \multicolumn{3}{|l|}{ Non-Liliaceae ${ }^{c}$} \\
\hline Bean & - & - \\
\hline Cauliflower & - & - \\
\hline Celery & - & - \\
\hline Pea & - & - \\
\hline Tomato & - & - \\
\hline Marigold & - & - \\
\hline Leek positive control & + & + \\
\hline All negative controls & - & - \\
\hline
\end{tabular}

a Results were similar for all strains tested.

${ }^{\mathrm{b}}$ All plants were spray inoculated with nutrient broth shake cultures. Each of 33 California leek $P$. syringae strains was individually inoculated onto the leek cultivars; other Allium spp. were inoculated with 10 individual strains. Negative controls were inoculated with sterile nutrient broth.

c Plants were spray or rub inoculated with four California leek P. syringae strains. Similar results were obtained for both inoculation methods; therefore, results for the two tests are combined. 
Fatty acid analysis. Whole cell fatty acid analysis was conducted with $20 P$. syringae strains from California leek and three strains of $P$. syringae pv. porri from France. The fatty acid profiles of these isolates were $>90 \%$ similar to the $P$. syrin- gae profile, which was consistent with the identification of these strains as $P$. syringae based on LOPAT characteristics. Using the MIDI software, similarity indexes $\geq 0.70$ are considered to be a match, with 1.0 considered a perfect match. When the profiles

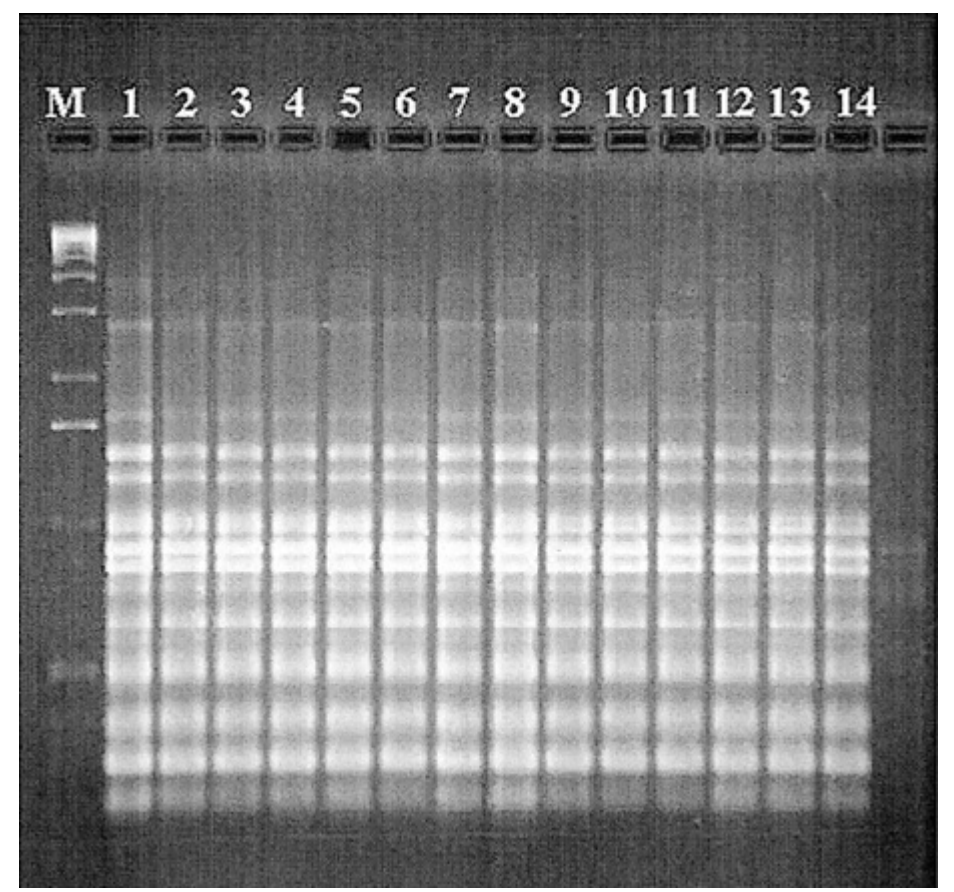

Fig. 1. Agarose gel electrophoresis of repetitive bacterial sequence-polymerase chain reaction (repPCR) fingerprint patterns obtained from genomic DNA from 14 of the 20 tested strains of Pseudomonas syringae isolated from diseased leek leaves or from leek seeds, using primers corresponding to the BOX element 1A sequence (BOX). PCR products $(10 \mu \mathrm{l})$ were loaded in each lane. The left lane contains DNA size markers (1-kilobase ladder, Gibco-BRL). PCR amplified fragments were resolved on $1.0 \%$ agarose gels stained with ethidium bromide.

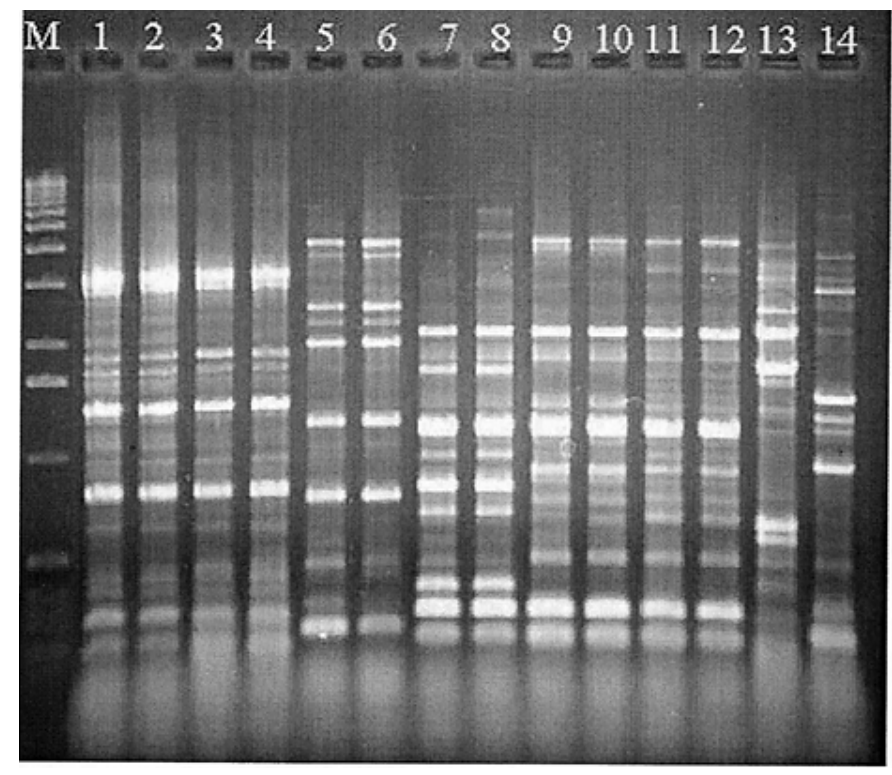

Fig. 2. Agarose gel electrophoresis of repetitive bacterial sequence-polymerase chain reaction (rep-PCR) fingerprint patterns obtained from genomic DNA from strains of Pseudomonas syringae, using primers corresponding to enterobacterial repetitive intergenic consensus (ERIC) sequences. PCR products $(10 \mu \mathrm{l})$ were loaded in each lane. The left lane contains DNA size markers (1-kilobase [kb] ladder, Gibco-BRL). PCR bands were resolved on 1.0\% agarose gels stained with ethidium bromide. Lane M, 1-kb ladder; lanes 1 and 2, California leek strains 96-89 and 96-75; lanes 3 and 4, P. syringae pv. porri strains 15 and 22; lanes 5 and 6, P. syringae pv. papulans strains a and b; lanes 7 and 8 P. syringae pv. maculicola strains 308 and 395; lanes 9 and 10, P. syringae pv. tomato strains 455 and 456; lanes 11 and $12, P$. syringae pv. apii strains 152 and 153; lane 13, P. syringae pv. phaseolicola strain 216; lane 14, P. syringae pv. pisi strain 539. of the leek $P$. syringae or the known $P$. syringae pv. porri strains were compared with profiles of other $P$. syringae strains in the gram-negative MIDI database, the closest matches were $P$. syringae pvs. papulans and coronafaciens. However, $P$. syringae pv. porri is not presently included in the gram-negative MIDI database.

Rep-PCR. Because rep-PCR DNA fingerprints can be used to differentiate $P$. syringae pathovars (14), REP, ERIC, and BOX primers were used to generate DNA fingerprints for the California leek $P$. syringae strains and various other $P$. syringae pathovars. The REP, ERIC, and BOX fingerprints generated for 20 strains of the California leek $P$. syringae were indistinguishable, suggesting that they were strains of the same bacterium (Fig. 1). The fingerprint generated for the California leek $P$. syringae strains was clearly distinct from those generated for $P$. syringae pvs. papulans, coronafaciens, pisi, phaseolicola, maculicola, tomato, and apii (Fig. 2). However, the fingerprint generated for the California leek $P$. syringae strains was indistinguishable from those generated for the known $P$. syringae pv. porri strains from France and Canada (Fig. 2). These results indicate that the $P$. syringae strains causing the leek disease in California are $P$. syringae pv. porri.

Nucleotide sequencing and comparison of the 16S-23S rDNA spacer region. The L1 and G1 primers directed the amplification of an approximately 600-base pair DNA fragment. The 16S-23S rDNA spacer region sequences determined from the amplified DNA fragment for three California leek $P$. syringae strains, one from seed and two from diseased plants, were $100 \%$ identical, and these sequences were $100 \%$ identical to the rDNA spacer region sequences of the known strains of $P$. syringae pv. porri from France. In contrast, nucleotide sequence differences were found when the $16 \mathrm{~S}-23 \mathrm{~S}$ rDNA spacer region sequence of the leek $P$. syringae was compared with those of $P$. syringae pvs. tomato, apii, maculicola, papulans, pisi, and phaseolicola (Fig. 3). These results further suggest that the $P$. syringae strains from leek in California are $P$. syringae pv. porri. The $16 \mathrm{~S}-23 \mathrm{~S}$ rDNA spacer region sequences were deposited in the Gene Bank.

Seed assay. With the seed wash assay, $P$. syringae pv. porri was recovered from both of the cv. Otina seed lots. Representative strains of these recovered bacteria were identified as $P$. syringae and were pathogenic on leek. In three assays of the two lots, an average of $10^{5} \mathrm{CFU} / \mathrm{g}$ seed was recovered. No $P$. syringae pv. porri was recovered from seed of two other leek cultivars (cvs. Jolant and Imperial).

\section{DISCUSSION}

This is the first report of a bacterial disease of leek in California. Evidence is provided that this foliar disease is caused 
by $P$. syringae pv. porri. This is based on the consistent association of a fluorescent $P$. syringae with this disease, the ability of representative strains of this bacterium to induce these disease symptoms, and characterization of the bacterium based on biochemical, fatty acid, and genetic properties.

Bacterial diseases of leek have been reported in the United Kingdom (Pseudomonas spp.; 10), New Zealand ( $P$. syringae; 4), Italy ( $P$. fluorescens, Erwinia carotovora var. carotovora, and $P$. syringae pv. syringae; 3,21), and France ( $P$. syringae; 19). However, the Pseudomonas spp. in these reports were not extensively characterized. Moreover, there appear to be some differences in pathogenicity among the $P$. syringae strains associated with the leek diseases in New Zealand, France, and California. The New Zealand strains were not pathogenic on chives and were weakly pathogenic on onion (4). The French strains, which have been named $P$. syringae pv. porri, were pathogenic only on leek (20). Our data suggests that the host range of $P$. syringae pv. porri may include leek, onion, chives, and garlic. The significance of the differences in the pathogenicity of leek $P$. syringae strains on Allium spp. hosts other than leek is not known and may relate to differences in the inoculation protocols.
The use of DNA fingerprints generated by amplification of repetitive sequences in the bacterial genome established that the California leek $P$. syringae strains were indistinguishable from previously described strains of $P$. syringae pv. porri. This method provides a rapid and precise way to identify plant pathogenic bacteria and has been used to differentiate pathovars of Xanthomonas campestris (14). The utility of this approach is further supported by the fact the other methods used in this study to characterize the California leek $P$. syringae strain to the pathovar level (i.e., fatty acid analysis and rDNA sequencing) failed to provide conclusive results. In the case of fatty acid analysis, this was probably due to the lack of $P$. syringae pv. porri in the database; whereas, for rDNA sequencing, it was due to the lack of significant sequence divergence in this region. That rDNA sequences are not sufficient to separate closely related pathovars was further demonstrated by the fact that $P$. syringae pvs. tomato, apii, and maculicola were not separated into their respective pathovars based on rDNA sequences. In contrast, these three pathovars were readily distinguishable by rep-PCR, which supports previous findings based on pathogenicity tests, DNA probes, and random amplified polymorphic DNAs (12) that these are closely related but distinct $P$. syringae pathovars.

The first-time appearance of this disease in California and its apparent rapid spread into various counties suggests a recent introduction of the pathogen via seed. We report here the apparent first documentation that this pathogen can be seedborne. The development of disease on seedlings grown in greenhouses, recovery of $P$. syringae pv. porri from leek seed, and the genetic homogeneity of the isolates associated with the disease in California support the hypothesis that the primary inoculum source was contaminated leek seed. This is further supported by the fact that most leek seed used in California is imported from Europe, where $P$. syringae pv. porri has been previously reported. Therefore, it appears likely that this pathogen was introduced to California in association with contaminated seed from Europe.

In terms of epidemiology, the present leek production system in California favors the development of bacterial blight. Leek seedlings are produced in greenhouses that often have high relative humidity. Plants are grown in transplant trays with high plant densities. Transplants are usually mowed, creating wounds for bacterial infection. Irrigation is always done with overhead sprinklers, which favors bacterial

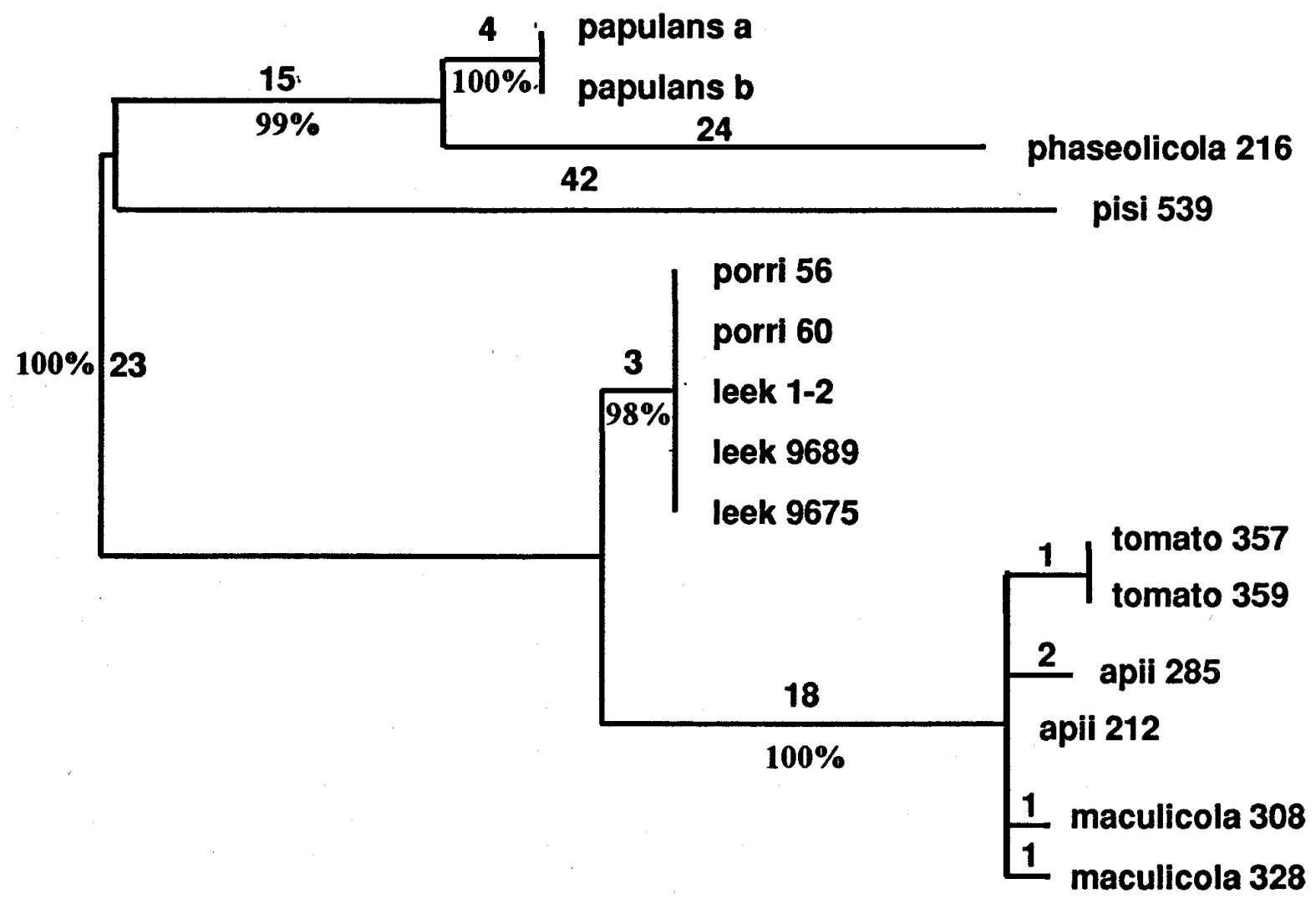

Fig. 3. Phylogenetic tree showing the relationship between California leek Pseudomonas syringae and other P. syringae pathovars based on alignment of the 16S-23S rDNA spacer region sequence. Sequences were analyzed by the computer program Phylogenetic Analysis Using Parsimony (PAUP, version 3.1) with heuristic tree construction. Branch strengths were evaluated by constructing 1,000 trees by bootstrap and branch swapping. The number of nucleotide changes is shown above the horizontal line and the percentage of trees having the given branch is shown below the horizontal line. Vertical distances are arbitrary and horizontal distances are in proportion to the number of nucleotide differences. 
dissemination. Once transplanted in the field, the crop is again sprinkler irrigated. These practices create ideal conditions for the establishment and spread of bacterial blight. Hence, assaying leek seed lots for $P$. syringae pv. porri and the use of seed treatments to reduce or eradicate seed contamination would be logical measures for managing this disease.

\section{ACKNOWLEDGMENTS}

We thank Golden Field Greenhouse for their cooperation and for partial financial support of this project; and D. A. Cooksey, T. D. Gonzales, L. Hirahara, H. Kinnaman, H. M. S. Koenraadt, M. Lamb, E. L. Little, S. Nicholson, H. Parra, B. Scatena, and $\mathrm{B}$. White for their assistance in this study.

\section{LITERATURE CITED}

1. California Agricultural Statistics Service. 1996. County Agricultural Commissioners' Data. U. S. Dep. Agric. and Calif. Dep. Food Agric.

2. Devereux, J., Haeberli, P., and Smithies, O. 1984. A comprehensive set of sequence analysis programs for the VAX. Nucleic Acids Res. 12:387-395

3. Garibaldi, d.-A., and Tamietti, G. 1977. Eziologia ed alcuni aspecti epidemiologici di marciumi batterici del porro in Liguria. Phytopathol. Mediterr. 16:27-29.

4. Hale, C. N. 1975. Bacteriosis of leeks in New Zealand. N. Z. J. Agric. Res. 18:251-254.

5. Jensen, M. A., Webster, J. A., and Straus, N. 1993. Rapid identification of bacteria on the basis of polymerase chain reaction-amplified ribosomal DNA spacer polymorphisms. Appl. Environ. Microbiol. 59:945-952.

6. Kado, C. I., and Heskett, M. G. 1970. Selec- tive media for isolation of Agrobacterium, Corynebacterium, Erwinia, Pseudomonas, and Xanthomonas. Phytopathology 60:969976.

7. King, E. O., Ward, M. K., and Raney, D. E. 1954. Two simple media for the demonstration of pyocyanin and fluorescin. J. Lab. Clin. Med. 44:301-307.

8. Koike, S. T., and Henderson, D. M. 1998. Purple blotch, caused by Alternaria porri, on leek transplants in California. Plant Dis. 82:710.

9. Koike, S. T., Henderson, D. M., Barak, J. D., and Gilbertson, R. L. 1997. A leaf blight disease of leek in California caused by Pseudomonas syringae, and association of the pathogen with seed. (Abstr.) Phytopathology 87:S53.

10. Lelliott, R. A. 1952. A new bacterial disease of leeks. Plant Pathol. 1:84.

11. Lelliott, R. A., Billing, E., and Hayward, A. C. 1966. A determinative scheme for the fluorescent plant pathogenic Pseudomonads. J. Appl. Bacteriol. 29:470-489.

12. Little, E. L., and Gilbertson, R. L. 1997. Phenotypic and genotypic characters support placement of Pseudomonas syringae strains from tomato, celery, and cauliflower into distinct pathovars. In: Pseudomonas syringae Pathovars and Related Pathogens. K. Rudolph, T. J. Burr, J. W. Mansfield, D. Stead, A. Vivian, and J. von Kietzell, eds. Kluwer Academic Publishers, Dordrecht, Netherlands

13. Little, E. L., Koike, S. T., and Gilbertson, R. L. 1997. Bacterial leaf spot of celery in California: etiology, epidemiology, and role of contaminated seed. Plant Dis. 81:892-896.

14. Louws, F. J., Fulbright, D. W., Stephens, C. T., and de Bruijin, F. J. 1994. Specific genomic fingerprints of phytopathogenic
Xanthomonas and Pseudomonas pathovars and strains generated with repetitive sequences and PCR. Appl. Environ. Microbiol. 60:2286-2295.

15. Mohan, S. K., and Schaad, N. W. 1987. An improved agar plating assay for detecting Pseudomonas syringae pv. syringae and $P$. s. pv. phaseolicola in contaminated bean seed Phytopathology 77:1390-1395.

16. Paisley, R. 1995. Page M-5 in: MIS Whole Cell Fatty Acid Analysis by Gas Chromatography. MIDI, Inc., Newark, DE.

17. Rademaker, J. L. W., and de Bruijn, F. J. 1997. Characterization and classification of microbes by rep-PCR genomic fingerprinting and computer assisted pattern analysis. In: DNA Markers: Protocols, Applications and Overviews. B. Caetano-Anolles and P. M. Gresshoff, eds. John Wiley \& Sons, New York.

18. Sambrook, J., Fritsch, E. F., and Maniatis, T. 1989. Molecular Cloning: A Laboratory Manual, 2nd edition (Book 3). Cold Spring Harbor Laboratory Press, New York.

19. Samson, R., Poutier, F., and Rat, B. 1981. Une nouvelle maladie du poireau: La graisse bacterienne a Pseudomonas syringae. Rev. Hortic. 219:20-23.

20. Samson, R., Shafik, H., Benjama, A., and Gardan, L. 1998. Description of the bacterium causing blight of leek as Pseudomonas syringae pv. porri (pv. nov.). Phytopathology 88:844-850.

21. Varvaro, L. 1983. Una batteriosi del porro (Allium porrum L.) in Puglia. Phytopathol. Mediterr. 22:86-88

22. Zhang, Y. P. 1996. Etiological study of cherry stem pitting disease and molecular characterization of sour cherry green ring mottle virus. Ph.D. diss. University of California, Davis. 